International Journal of Life Sciences
Available online at http://sciencescholar.us/journal/index.php/ijls
Vol. 3 No. 2, August 2019, pages: $33 \sim 40$
e-ISSN: 2550-6986, p-ISSN: 2550-6994
https://doi.org/10.29332/ijls.v3n2.305

\title{
Utilization of Piper Caninum Blume Leaf Extract Combined with Compost to Suppress Blast Disease and Increase the Growth of Local Rice Bali (Oryza Sativa) in Vivo
}

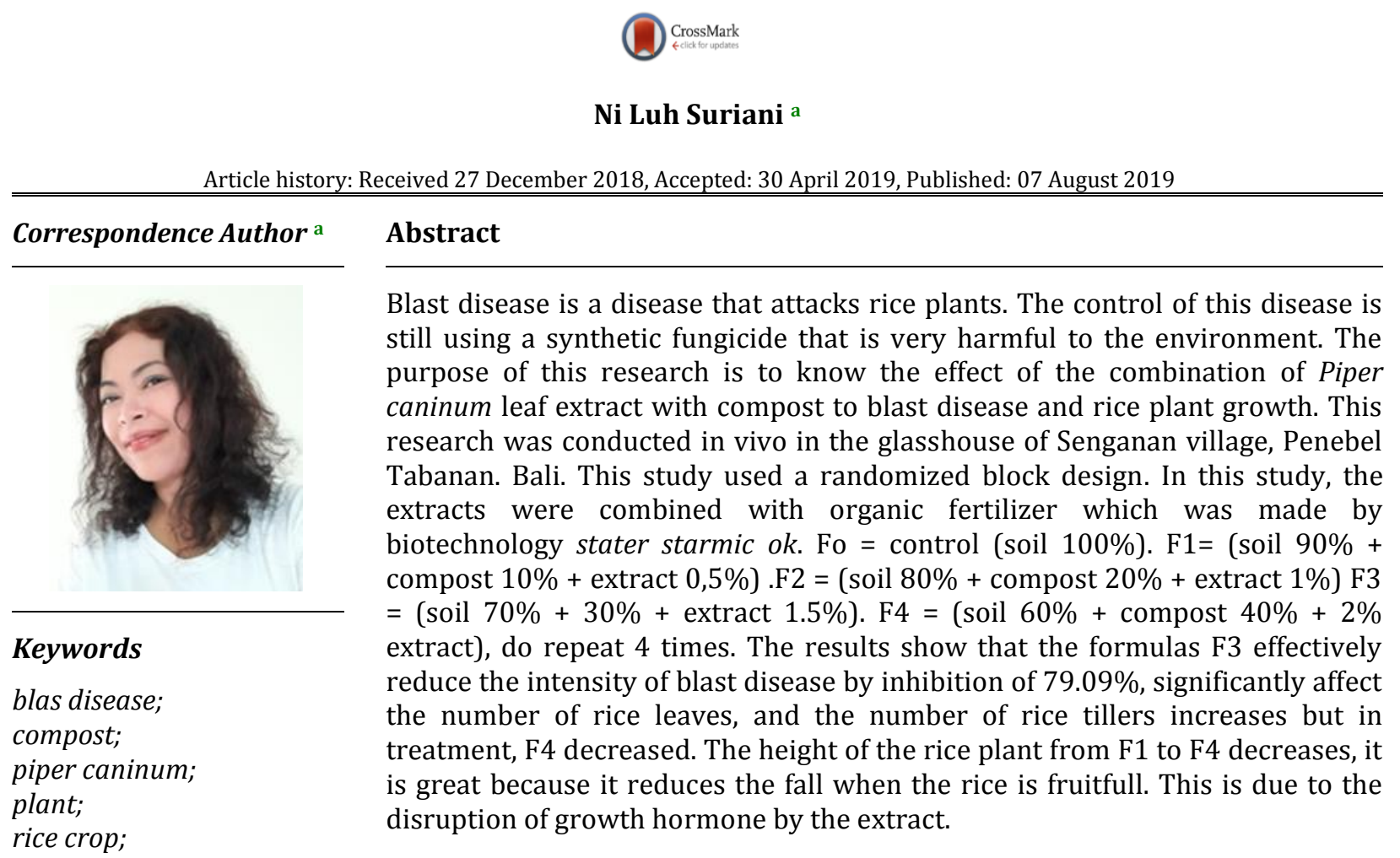

e-ISSN: 2550-6986, p-ISSN: 2550-6994C Copyright 2019. The Author. SS Journals Published by Universidad Técnica de Manabí. This is an open-access article under the CC BY-SA 4.0 license (https://creativecommons.org/licenses/by-sa/4.0/) All rights reserved.

\section{Contents}

Abstract 33

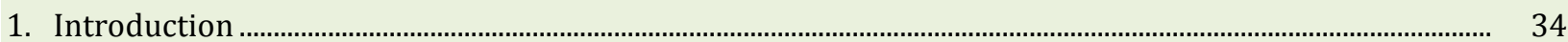

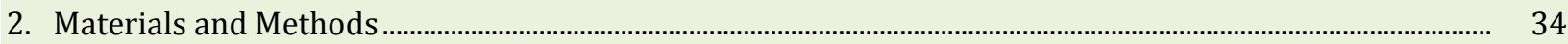

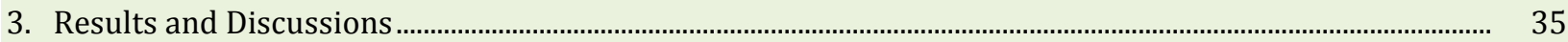

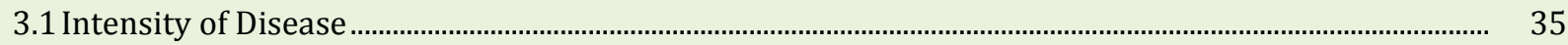

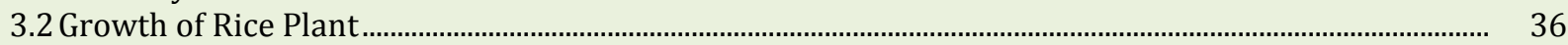

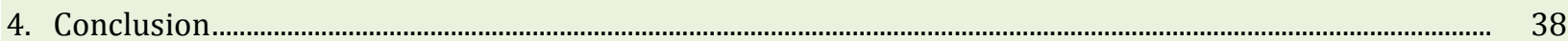

a Udayana University, Denpasar, Indonesia 


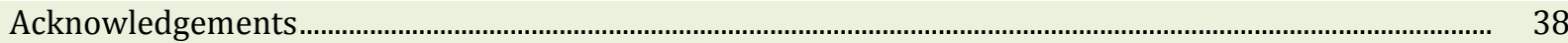

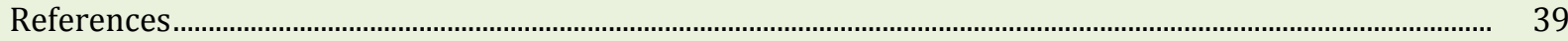

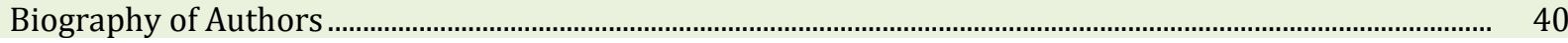

\section{Introduction}

One of the important diseases in rice is blast disease, caused by the fungus $P$. oryzae. This fungus can infect rice plants at different growth stages (Yolanda, 2013). Blast disease is capable of lowering the enormous yield, causing production loss up to $50 \%$ in endemic areas. Blast disease poses two typical symptoms, i.e. leaf blast and panicle blast. Blast leaves are dark brown spots, rhombic with white patches center. Panicle blast is in the form of dark brown spots on the base of the neck that can cause neck panicles not to be able to sustain and get broken. Control of this disease is very difficult, but it is generally done by planting resistant varieties interchangeably to anticipate changes of blast race very fast (Utami, 2006).

Control of blast disease by farmers is still using synthetic fungicides if done less precisely; it can have a negative impact on the ecosystem of paddy crop. The use of botanical pesticides for controlling plant diseases is one alternative that is safe for environment control, but its use has not been widely practiced in Indonesia (Rahmawati \& Corlina, 2009). Blast disease can be controlled by using microbial antagonists such as Enterobacter agglomerans, Seratia liguefaciens Xanthomonas lumenescens, and Tricodherma harzianum (Suprapta, 2012; Suprapta et al., 2014; Gouramanis, 1997). Many types of plants in Indonesia contain active ingredients that can be used as a plantpesticide. In applying the plant pesticide, usually, one thing that needs to be done is the making of an effective formula, which is done on the greenhouse scale research and continued in the field (Suprapta, 2014). Blast disease can be controlled by using compost extract and leaf Piper caninum extracted by inhibity 83,31\% at a concentration 2,5\% (Suwandi et al., 2012; Suriani et al., 2015).

But research using this extract has a weakness because too many extracts are used. Based on the above, there needs to be integrated blast disease control so that the extract used is not too much. Blast disease control by combining plant extract with compost organic fertilizer has not been done especially in Bali. This control will produce appropriate technology that is environmentally friendly. This method is one way that supports the government program that is developing organic farming. The purpose of this research is to explore the optimal potency of chili leaf extract combined with compost organic fertilizer as a biopesticide against blast disease in rice plant and to get the right formula from the extract which combined by compost in pressing blast disease on rice and spur rice plant growth.

\section{Materials and Methods}

P. canium leaf samples were taken from the Senganan Penebel Tabanan area of Bali. Samples were taken at noon, the samples were cut into small pieces and air-dried for 5 days, then blended and soaked with methanol for 3 days, then filtered with gauze. Then evaporated using an evaporator. The crude extract is ready to use. This research was conducted at the UNUD biopesticide lab.

In this study the extracts were combined with organic fertilizer which was made by biotechnology stater starmik ok. Fo = control $($ soil 100\%). F1= (soil 90\% + compost 10\% + extract 0,5\%) .F2 = (soil 80\% + compost $20 \%+$ extract $1 \%) \mathrm{F} 3=($ soil $70 \%+30 \%+$ extract $1.5 \%) \cdot \mathrm{F} 4=($ soil $60 \%+$ compost $40 \%+2 \%$ extract $)$, do repeat 4 times. Green house experiments were carried out in the village of Senganan, Penebel District, Tabanan Regency, Bali Province using a randomized block design (RBD) consisting of 5 treatments: Each experimental unit consisted of 10 clumps rice plants. Implementation of the experiment include: seeding, planting media preparation, fertilizing, plant maintenance, inoculation of pathogenic fungi ( $P$. oryzae), vegetable fungicide application.

The observed parameters covered intensity of blast disease, growth parameters (plant height, number of tillers, amount of leaf) Measurement of the intensity of the blast disease was done by the following formula

(Sinaga, 2006). I P $=\frac{\sum_{i=0}^{i}(n i . v i)}{N V} x 100 \%$. Where IP = Intensity of disease (\%), ni = Number of leaves with score i, $\mathrm{vi}=$ Value of each category of disease scores, $\mathrm{N}=$ number of leaves were observed, $\mathrm{V}=$ highest score. 


\section{Results and Discussions}

\subsection{Intensity of Disease}

The results showed that the treatment of chili leaf extract combined with compost gave a significant effect $(\mathrm{P}<0.05)$. Suppressing blast disease in red Bali rice plants after 8 MST (Table 1). 1.5\% extract combined with $30 \%$ compost and $70 \%$ soil have the highest inhibitory (Figure 1). The higher concentration of organic extract and fertilizer then the intensity of blast disease decreased until the concentration of extract $1.5 \%$ and the concentration of organic fertilizer $30 \%$. While the concentration of $2 \%$ extract combined with $40 \%$ organic fertilizer increases disease intensity, which shows more blotches (Figure 1). This possibility is due to the presence of toxic factors by the extract so that the resistance of rice plants weakens. The extract contains polar and non polar compounds, non-polar substances are destructive to wax coating on leaves if the concentration is excessive (Suprapta, 2014; Sukada et al., 2019). In addition, it can also be caused by the content of substances contained allelopathy extract that can disrupt the growth of plants. Research Djazuli (2011), showed that the allelopathic substances on nilam leaves damage the soil. The concentration of organic fertilizer is too high in the soil also causes a nutrient imbalance in the soil, there the micro-nutrients are reduced so that can not be absorbed by plants. It is also shown by Padmanabha et al., (2014), research that the addition of organic fertilizer is too high cause the decrease of yield and growth of rice plants.

Table 1

The intensity of blast disease and inhibiting activity after 9MST

\begin{tabular}{llll}
\hline No & Treatment & Intensity of blast disease (\%) & Inhibiting activities (\%) \\
\hline 1 & F0 & $79,10 \mathrm{a}^{*}$ & - \\
2 & F1 & $50,14 \mathrm{~b}$ & 28,96 \\
3 & F2 & $30,07 \mathrm{c}$ & 49,30 \\
4 & F3 & $9,01 \mathrm{e}$ & 79,09 \\
5 & F4 & $15,14 \mathrm{~d}$ & 63,96 \\
\hline
\end{tabular}

* Figures followed by the same letter do not show significant difference based on Duncan multiple range test at the level of $5 \%$. (F0 = control; F1=extract $5 \%+$ compost $10 \%$; F2 = extract $1 \%+$ compost $20 \%$; F3= extract $1,5 \%+$ compost $30 \% ; \mathrm{F} 4=$ extract $2 \%+$ compost $40 \%)$.

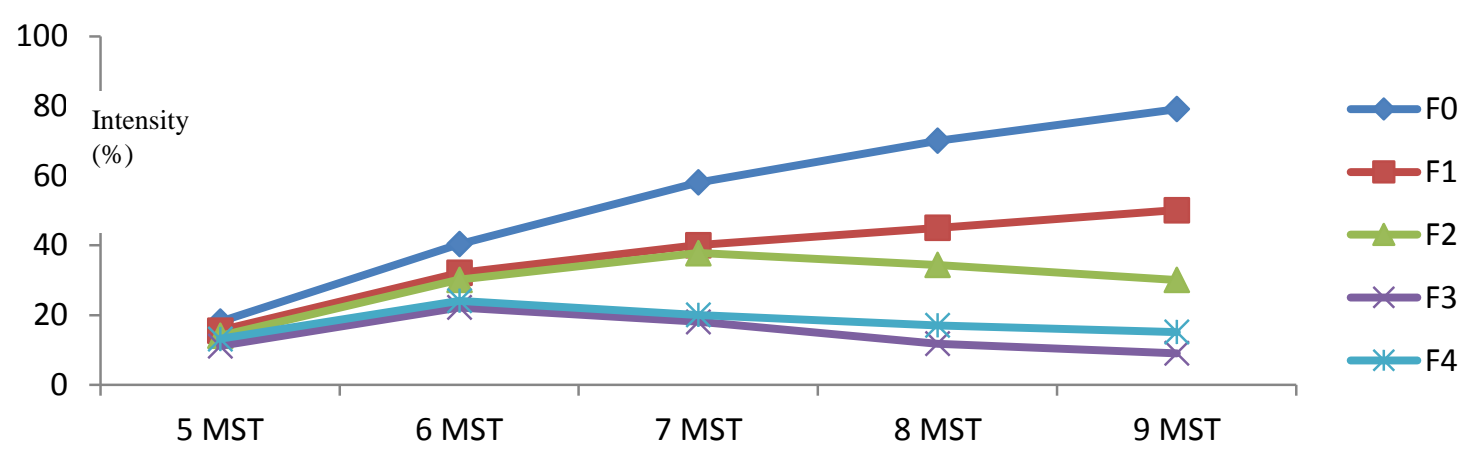

Figure 1. Intensity development of blast disease during spraying with extracts

Title Suriani, N. L. (2019). Utilization of piper caninum blume leaf extract combined with compost to suppress blast disease and increase the growth of local rice Bali (Oryza sativa) in Vivo. International Journal of Life Sciences, 3(2), 33-40. https://doi.org/10.29332/ijls.v3n2.305 


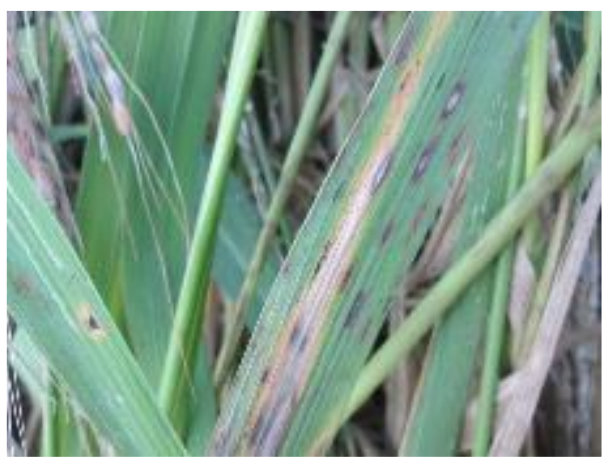

F0

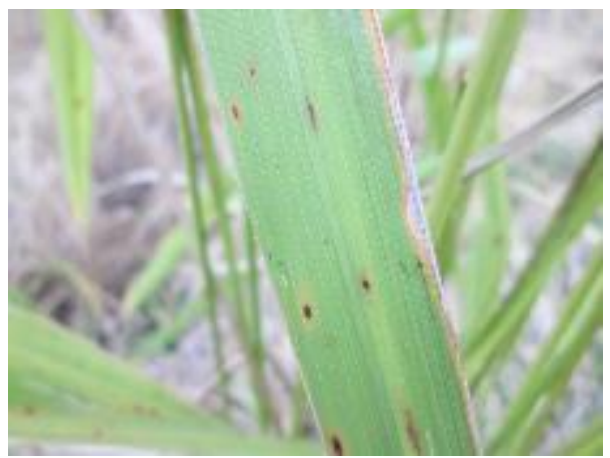

F2

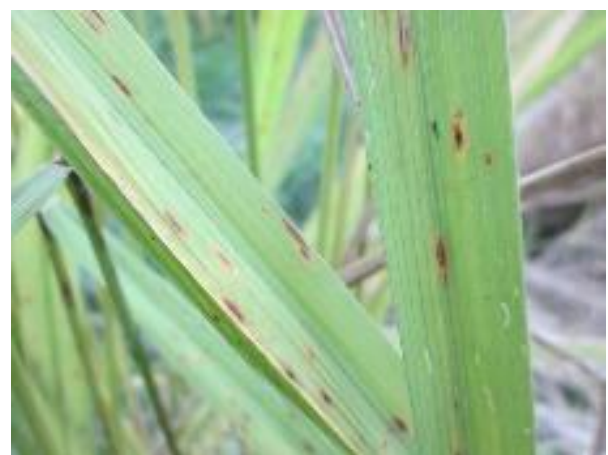

F1

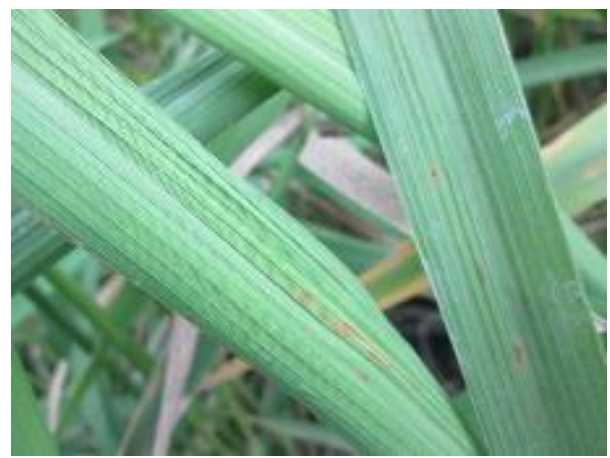

F3

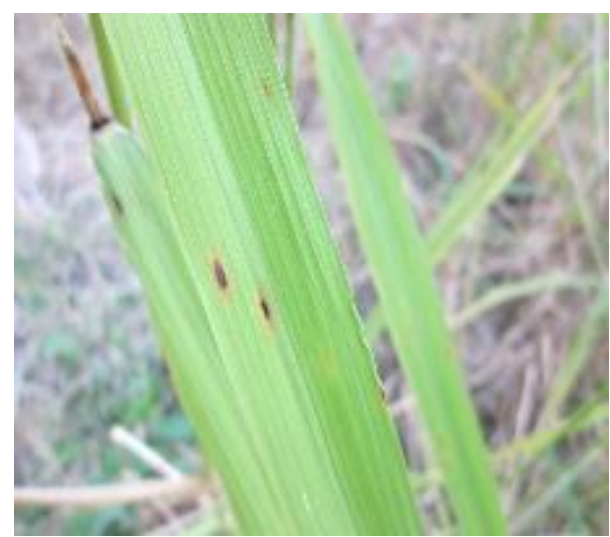

F4

Figure 2. Spotting blast disease for each treatment

\subsection{Growth of Rice Plant}

The result of the research showed that the combination of chili leaf extract had a significant effect on the number of tillers (table 2) and the number of leaves (Table 3) $(\mathrm{P}<0,05)$. The higher the treatment concentration, the number of tillers and the number of leaves increased until treatment F3: 1.5\% extract concentration and 30\% compost concentration and decreased at $2 \%$ extract concentration and $40 \%$ compost. This is caused by the higher the concentration of treatment, the intensity of blast disease decreases until the treatment of F3. While the treatment of F4 blass disease intensity decreased, this is probably due to decreased resistance of rice crops so that the intensity of blast disease increased. Suriani research 2015 chili leaf extract can suppress the highest blast disease intensity at $2.5 \%$ concentration and decrease its inhibitory 
concentration at 3.5\% in ciherang rice plant. Research Irsan et al., (2012), states that the compost extract significantly affects the growth of rice plants, increasing K. uptake.

According to Suriani (2016); Suriani (2018); and Suriani et al., (2019), treatment of compost extracts and organic fertilizer on rice plants can increase plant growth, because the extract contains growth hormone and compost contains nutrients needed by plants. The extract also suppresses blast disease because it contains phytochemicals (Salleh et al., 2011; 2015) If the extract is too high, it causes the waxy coating on the leaves to be damaged so that photosynthesis will be disrupted (Suprapta, 2014). The results of the study for the parameters of plant height showed that there was a decrease from F2 to F4. The higher the treatment concentration, the higher the crop begins the treatment of $1 \%$ extract and $20 \%$ compost, the height of the rice plant decreased (Table 3). This is probably due to disruption of growth hormone by the extract, and the absorption of nutrients is not balanced so that the rice crop becomes shorter. This is very advantageous in the field because with the reduced height of the plant, then reduces the fall when the rice is fruitfull. Research Padmanabha et al., (2014), that the addition of organic fertilizer is too high cause the decrease of rice plant growth.

Table 2

Effect of the extract on the average number of tillers of the rice plant (age 60 days after planting)

\begin{tabular}{ll}
\hline Treatment $(\%)$ & Number of tillers \\
\hline F0 & $8,10 \mathrm{a}^{*}$ \\
F1 & $9,50 \mathrm{ab}$ \\
F2 & $11,15 \mathrm{c}$ \\
F3 & $13,69 \mathrm{~d}$ \\
F4 & $10,46 \mathrm{bc}$ \\
\hline
\end{tabular}

Table 3

Effect of extract on the average number of the height of rice plant (age 60 days after planting)

\begin{tabular}{ll}
\hline Treatment $(\%)$ & Plant Height $(\mathrm{cm})$ \\
\hline F0 & $187,77 \mathrm{a}^{*}$ \\
F1 & $187,12 \mathrm{a}$ \\
F2 & $173,75 \mathrm{c}$ \\
F3 & $161,50 \mathrm{~d}$ \\
F4 & $157,88 \mathrm{~b}$ \\
\hline
\end{tabular}

Table 4

Effect of extract on the average number of leaf of rice plant (age 60 days after planting)

\begin{tabular}{ll}
\hline Treatment (\%) & Number of leaf \\
\hline F0 & $28,39 \mathrm{a}^{*}$ \\
F1 & $30,55 \mathrm{a}$ \\
F2 & $35,12 \mathrm{~b}$ \\
F3 & $40,02 \mathrm{c}$ \\
F4 & $31,30 \mathrm{a}$ \\
\hline
\end{tabular}

Title Suriani, N. L. (2019). Utilization of piper caninum blume leaf extract combined with compost to suppress blast disease and increase the growth of local rice Bali (Oryza sativa) in Vivo. International Journal of Life Sciences, 3(2), 33-40. https://doi.org/10.29332/ijls.v3n2.305 


\section{Conclusion}

Leaf extract of forest chili in combination with compost significantly affects the growth and production of Bali red rice. The most appropriate formula to increase production is $1.5 \%$ extract concentration combined with $30 \%$ compost.3. 1.5\% extract concentration combined with $30 \%$ compost can increase the growth of Bali red rice.

\section{Acknowledgments}

We would like to thank DIKTI has funded this research which has funded this research, and the Lab. Biopesticide Unud which has facilitated the implementation of this research. 
References

Djazuli, M. U. H. A. M. A. D. (2011). Alelopati pada Beberapa Tanaman Perkebunan dan Teknik Pengendalian Serta Prospek Pemanfaatannya. Jurnal Perspektif, 10(1), 44-50.

Gouramanis, G. D. (1995). Biological and chemical control of rice blast disease (Pyricularia oryzae) in Northern Greece. CIHEAM-Options Mediterraneennes, 15.

Irsan, C. (2012). Application of extract compost increased yield and suppressed the diseases of ratoon rice crop in tidal swamp of Banyuasin Regency. J. Lahan Suboptimal, 1(2), 116-122.

Padmanabha, I. G., Arthagama, I. D. M., \& Dibia, I. N. (2014). Pengaruh dosis pupuk organik dan anorganik terhadap hasil padi (Oriza sativa L.) dan sifat kimia tanah pada Inceptisol Kerambitan Tabanan. E-Jurnal Agroekoteknologi Tropika, 3(1), 41-50.

Rachmawati, D., \& Karlina, E. (2009). Pemanfaatan Pestisida Nabati untuk Mengendalikan Organisme Pengganggu Tanaman. Balai Pengkajian Teknologi Pertanian Jawa Timur, Departemen Pertanian.

Salleh, W. M. N. H. W., Ahmad, F., \& Yen, K. H. (2015). Chemical constituents from Piper caninum and antibacterial activity. Journal of Applied Pharmaceutical Science, 5(06), 020-025.

Salleh, W. M. N. H. W., Ahmad, F., Yen, K. H., \& Sirat, H. M. (2011). Chemical compositions, antioxidant and antimicrobial activities of essential oils of Piper caninum Blume. International journal of molecular sciences, 12(11), 7720-7731.

Sinaga, P. (2006). Pasar Modern VS Pasar Tradisional. Jakarta: Kementerian Koperasi dan UKM.

Sukada, I. K., Suberata, I. W., \& Rasna, N. M. A. (2019). Immersion effect with extracts of papaya leaf, pineapple, ginger on quality of organoleptic and Bali beef nutrition. International Journal of Life Sciences, 3(1), 12-24. https://doi.org/10.29332/ijls.v3n1.241

Suprapta, D. N. (2012). Potential of microbial antagonists as biocontrol agents against plant fungal pathogens. J ISSAAS, 18(2), 1-8.

Suprapta, D. N. (2014). Pestisida Nabati: Potensi dan Prospek Pengembangan. Penerbit Pelawa Sari. Denpasar. Suprapta, D. N. (2014). Pestisida Nabati: Potensi dan Prospek Pengembangan. Penerbit Pelawa Sari. Denpasar.

Suprapta, D. N., \& Khalimi, K. (2012). Anti-fungal activities of selected tropical plants from Bali Island. Phytopharmacology, 2(2), 265-270.

Suprapta, D. N., Maulina, N. M. I., \& Khalimi, K. (2014). Effectiveness of Enterobacter cloacae to Promote the Growth and Increase the Yield of Rice. Journal of Biology, Agriculture and Healthcare, 4(1), 44-50.

Suprapta, D. N., Quintao, V., \& Khalimi, K. (2014). Effectiveness of rhizobacteria to reduce rice blast disease intensity. Journal of Biology, Agriculture and Healthcare, 4(3), 35-41.

Suriani, N. L. (2016). Identification of the substance bioactive leaf extract Piper Caninum potential as botanical pesticides. Int J Pure App Biosci, 4(4), 26-32.

Suriani, N. L. (2018). Bioactive substance use of leaf extract of piper caninum blume pressing for blas disease and increase production in rice. International Journal of Life Sciences,2(2), 42-50. https://doi.org/10.29332/ijls.v2n2.156

Suriani, N. L., Darmadi, A. A. K., Parwanayoni, N. M. S., Hamid, M. H. N. A., \& Yamin, B. M. (2019). The combination of piper Caninum Blume leaf extract and compost fertilizer for pressing blast disease and improving growth of bali red rice (Oryza Sativa Linn). International Journal on Advanced Science, Engineering and Information Technology, 9(2), 518-525.

Suriani, N. L., Parwanayoni, N. M. S., \& Suartini, N. M. (2015). Meningkatkan produksi bunga potong anthurium sp melalui pemanfaatan pupuk organik. Buletin Udayana Mengabdi, 15(2), 19-23.

Suriani, N. L., Suprapta, D. N., Sudana, I. M., Temaja, I. R. M., \& Indonesia, D. B. (2015). Antifungal activity of Piper caninum against Pyricularia oryzae Cav. The cause of rice blast disease on rice. Methods, 5(8).

Suryani, S. A. M. P., \& Arya, I. W. (2017). Improving the quality of tilapia (oreochromis niloticus) with consumption measures leaf extract neem (azadirachta indica a. juss) as antiparasitic. International Journal of Life Sciences, 1(3), 28-37. https://doi.org/10.21744/ijls.v1i3.62

Suwandi, A. C., Indraswati, N., \& Ismadji, S. (2012). Adsorption of N-methylated diaminotriphenilmethane dye (malachite green) on natural rarasaponin modified kaolin. Desalination and Water Treatment, 41(1-3), 342-355. https://doi.org/10.1080/19443994.2012.664738

Utami, W. Christina, 2006. Manajemen Ritel, Jakarta, Salemba Empat.

Yolanda, K. (2013). Penyakit Blas Pada Padi. BPTP Bangka Balitung, Balitbang Pertanian RI: Pangkalpinang, Indonesia.

Title Suriani, N. L. (2019). Utilization of piper caninum blume leaf extract combined with compost to suppress blast disease and increase the growth of local rice Bali (Oryza sativa) in Vivo. International Journal of Life Sciences, 3(2), 33-40. https://doi.org/10.29332/ijls.v3n2.305 


\section{Biography of Author}

Dr. Ni Luh Suriani, SSi., M.Si. graduated her bachelor degree in Udayana University.
She finished her master degree in the Institute of Pertanian Bogor. She completed
her doctoral degree in Udayana University. She is interested in Biology,
Environmental, and Agriculture.
Email: niluhsurianisuriani@yahoo.com

